\title{
Evaluation of recombinant Brachyspira pilosicoli oligopeptide-binding proteins as vaccine candidates in a mouse model of intestinal spirochaetosis
}

\author{
Abdolreza Movahedi and David J. Hampson
}

Correspondence

David J. Hampson

d.hampson@murdoch.edu.au

Received 6 September 2009

Accepted 1 December 2009

\author{
Division of Health Sciences, School of Veterinary and Biomedical Sciences, Murdoch University, \\ Murdoch, Western Australia 6150, Australia
}

\section{INTRODUCTION}

Brachyspira pilosicoli is a weakly haemolytic anaerobic spirochaete that colonizes the large intestine of human beings, and a number of species of animals and birds, notably chickens, pigs, dogs and horses (Hampson et al., 2006). In pigs the infection can lead to diarrhoea and poor growth rates (Hampson \& Duhamel, 2006), and in adult chickens it is associated with wet faeces and reduced egg production (Hampson \& Swayne, 2008). In humans, colonization may result in various non-specific problems, including abdominal pain, chronic diarrhoea and a failure to thrive in children (Douglas \& Crucioli, 1981; Peghini et al., 2000; Brooke et al., 2006; Esteve et al., 2006). B.

Abbreviations: HRP, horseradish peroxidase; IS, intestinal spirochaetosis. The GenBank/EMBL/DDBJ accession numbers for the B. pilosicoli sequences reported in this work are GQ478427-GQ.478432.

Tables of primer sequences are available as supplementary data with the online version of this paper. pilosicoli also has been isolated from the bloodstream of critically ill and immunocompromised patients (FourniéAmazouz et al., 1995; Trott et al., 1997b; Kanavaki et al., 2002; Bait-Merabet et al., 2008; Zeeshan et al., 2009). Although intestinal spirochaetosis (IS) caused by $B$. pilosicoli is not commonly reported in the general western population, the spirochaete is found at a high prevalence amongst people who live in conditions of poor hygiene in rural areas of developing countries (Trott et al., 1997a; Margawani et al., 2004), in indigenous populations such as Australian Aboriginals (Lee \& Hampson, 1992), in homosexual males (Trivett-Moore et al., 1998) and in people infected with human immunodeficiency virus (Käsbohrer et al., 1990).

Control of IS largely relies on the use of antimicrobials, although drug resistance in B. pilosicoli is quite widespread (Mortimer-Jones et al., 2008). Commercial vaccines for IS are not available, and an autogenous bacterin vaccine failed to protect pigs that were experimentally infected with $B$. 
pilosicoli (Hampson et al., 2000). Since vaccines based on recombinant proteins have been developed for the related spirochaete Brachyspira hyodysenteriae (La et al., 2004; Song et al., 2009), the use of similar recombinant proteins was worth investigating for $B$. pilosicoli. Oligopeptidebinding proteins (OppA) are part of the ATP-binding cassettes $(\mathrm{ABC})$ that function in the transport of proteins across the bacterial cell envelope. Different forms of these permeases may be potential virulence determinants in various bacterial species, including spirochaetes (Hiron et al., 2007; Veith et al., 2009; Wu et al., 2007). Antibodies against OppA are found in patients with early Lyme disease (Nowalk et al., 2006), and recombinant OppA has been used successfully as a vaccine to provide protection in mice experimentally infected with Yersinia pestis (Tanabe et al., 2006). The purpose of the current study was to identify genes predicted to encode OppA-like oligopeptide-binding proteins in $B$. pilosicoli, and to test the recombinant proteins as potential vaccine candidates in a mouse model of IS.

\section{METHODS}

Permissions. The infection studies were conducted with the approval of the Murdoch University Animal Ethics Committee, under permit number R2104/07.

Spirochaete strains and cultivation. A total of 27 well-characterized strains of B. pilosicoli were used in the study, including 20 from pigs and 7 from humans. Twenty-one of the strains were isolated in Australia, and two each were from the UK, the USA and Italy. The strains were obtained as frozen stocks from the culture collection held at the Reference Centre for Intestinal Spirochaetes, School of Veterinary and Biomedical Sciences, Murdoch University. They were thawed, and grown on trypticase soy agar (TSA) (Sigma-Aldrich) plates containing $5 \%(\mathrm{v} / \mathrm{v})$ defibrinated ovine blood. The plates were incubated for $7-10$ days at $37{ }^{\circ} \mathrm{C}$ in an anaerobic environment $(94 \%$ $\mathrm{N}_{2}, 6 \% \mathrm{CO}_{2}$ ) generated using anaerobic GasPak Plus sachets (BBL). The purity of the cultures was examined by phase-contrast microscopy, and cells were propagated in modified Kunkle's prereduced anaerobic broth, containing $3.5 \%(\mathrm{v} / \mathrm{v})$ fetal calf serum and $0.5 \%(\mathrm{v} / \mathrm{v})$ newborn calf serum (Kunkle et al., 1986).

Genomic sequencing and in silico analysis. The genome of Australian porcine B. pilosicoli strain $95 / 1000$ was partially sequenced using a shotgun sequencing approach at the Australian Genome Research Facility, University of Queensland, Brisbane, Queensland, Australia, under a commercial contract, as previously described (Motro et al., 2008). Phred was used for fragment assembly (Ewing et al., 1998), with subsequent viewing using Consed (Gordon et al., 1998). ORF identification was carried out using Glimmer and GeneMark (Lukashin \& Borodovsky, 1998; Salzberg et al., 1999). BLAST (www.ncbi.nlm.nih.gov/blast) was used to search for similarity between the query sequences and sequences in the nucleotide database BLASTN and peptide database BLASTP (Altschul et al., 1990). Pfam (Bateman et al., 2002) and CDD (Marchler-Bauer et al., 2003) were searched to determine the structural and functional building blocks of ORF products or protein domains. PSORTb version 2.0 (http:// www.psort.org/psortb/) (Nakai, 2000), SignalP version 3.0 HMM (http://www.cbs.dtu.dk/services/SignalP/) (Bendtsen et al., 2004), LipoP (http://www.cbs.dtu.dk/services/LipoP/) and TMpred (http:// www.ch.embnet.org/software/TMPRED_form.html) were used to predict the subcellular localization of the ORF products. Six ORFs predicted to encode membrane-associated oligopeptide or amino acid-binding ABC-type transporter proteins were selected for further analysis. These were given a temporary designation as ORF-1 through ORF-6, with their products given the corresponding name P-1 through P-6. The nucleotide sequences were deposited in GenBank, and the accession numbers are listed in Table 1.

Gene distribution analysis by PCR. Pairs of primers that annealed to internal regions of the ORFs were designed using SeqEd version 1.0.3 and the Amplify program version 1.2 (University of Wisconsin) (Supplementary Table S1 available with the online journal), and the distribution of the ORFs amongst the strains of B. pilosicoli was analysed by PCR. The amplification mixtures consisted of $1 \times$ PCR buffer, $1.5 \mathrm{mM} \mathrm{MgCl}_{2}$, 0.6 U Taq DNA polymerase, $0.25 \mathrm{mM}$ each dNTP (Promega), $0.5 \mu \mathrm{M}$ of the primer set, and $50-100 \mathrm{ng}$ chromosomal DNA template in a total reaction volume of $25 \mu \mathrm{l}$ or $50 \mu$. The reactions were loaded into $0.2 \mathrm{ml}$ thin-walled thermocycler tubes (Multiply-Pro) and Ultrapure water (Fisher Biotech) was used to make up the reaction volume. Thermocycling conditions consisted of an initial template denaturation for $5 \mathrm{~min}$ at $94{ }^{\circ} \mathrm{C}$, followed by $30-35$ cycles of denaturation at $94{ }^{\circ} \mathrm{C}$ for $30 \mathrm{~s}$, annealing at $57^{\circ} \mathrm{C}$ for $30 \mathrm{~s}$, and primer extension at $72{ }^{\circ} \mathrm{C}$ for $1-1.5 \mathrm{~min}$. The final cycle had the extension time increased to $7 \mathrm{~min}$ to complete synthesis of all strands. The amplified products were separated by electrophoresis using $1.2 \%(\mathrm{w} / \mathrm{v})$ agarose in $1 \times \mathrm{TAE}$ buffer $(40 \mathrm{mM}$ Tris/acetate, $1 \mathrm{mM}$ EDTA), stained by immersion in a $1 \mu \mathrm{g}$ ethidium bromide $\mathrm{ml}^{-1}$ solution and viewed with UV light.

Preparation of recombinant histidine-tagged proteins. The ORFs were amplified from human B. pilosicoli strain WesB using the primers listed in Supplementary Table S2 (available with the online journal). The PCR was performed as for the gene distribution study, except for using $0.06 \mathrm{U} P f u$ DNA polymerase and $12.5 \mathrm{pM}$ each primer. The amplified products were restricted with EcoRI and BamHI (New England Biolabs), in a double digest according to the manufacturer's instructions. The restricted insert DNAs were purified using the UltraClean PCR clean-up kit and cloned into the pTrcHis A vector (Invitrogen) according to the manufacturer's instructions. Recombinant histidine-tagged proteins were expressed in E. coli BL21 Star (DE3) pLys (Invitrogen) grown in 2YT medium supplemented with $100 \mu \mathrm{g}$ ampicillin $\mathrm{ml}^{-1}, 0.5-1 \mathrm{mM}$ IPTG and $0.1-1 \%(\mathrm{w} / \mathrm{v})$ glucose. The recombinant $\mathrm{His}_{6}$-proteins were purified by affinity chromatography using nickel nitrilotriacetic acid metal affinity chromatography (Qiagen), conducted as described in the QIAexpressionist handbook. The purified proteins were dialysed against distilled water, and then lyophilized and resuspended in PBS ( $\mathrm{pH}$ 7.2). Quantification of recombinant His $_{6}$-proteins was carried out by loading serial dilutions of BSA and lysozyme protein standards $(100,250,500,1000 \mathrm{ng})$ on an SDS-PAGE gel, then acquiring gel images using a densitometer (proxPRESS proteomic imaging system; PerkinElmer Life Science). The images were analysed using the Proteome 1D analyser version v 1.10 (PerkinElmer Life Science) to calculate the protein concentrations.

Whole-cell protein preparations of B. pilosicoli. Cells of $B$. pilosicoli strain WesB were centrifuged at $1000 \mathrm{~g}$ for $10 \mathrm{~min}$ at $4{ }^{\circ} \mathrm{C}$, resuspended in cold PBS and washed three times. The cells were suspended at a concentration of $10^{8} \mathrm{cells} \mathrm{ml}^{-1}$ in PBS, and subjected to four cycles of freeze-thawing followed by sonication on ice for four cycles of $30 \mathrm{~s}$ with a $2 \mathrm{~min}$ pause between cycles. The sonicate was centrifuged at $10000 \mathrm{~g}$ for $30 \mathrm{~min}$ and the supernatant was separated for use in a blot assay. The total protein concentration was quantified using the Bio-Rad Protein assay kit, according to the manufacturer's instructions.

Preparation of mouse polyclonal antiserum against $B$. pilosicoli strain WesB. A whole cell bacterin was prepared from $B$. 
Table 1. Results of bioinformatics analysis of the six ORFs selected for further investigation

\begin{tabular}{|c|c|c|c|c|c|c|}
\hline $\begin{array}{l}\text { Temporary } \\
\text { locus ID }\end{array}$ & $\begin{array}{c}\text { GenBank } \\
\text { accession no. }\end{array}$ & Putative identity (e value) & $\begin{array}{c}\text { Signal } \\
\text { peptide } \\
(\text { SignalP })\end{array}$ & $\begin{array}{l}\text { TM helices } \\
\text { (TMpred) }\end{array}$ & $\begin{array}{c}\text { Lipoprotein } \\
\text { (LipoP 1.0) }\end{array}$ & $\begin{array}{c}\text { Theoretical } \\
\text { molecular } \\
\text { mass of } \\
\text { product } \\
(\mathrm{kDa})\end{array}$ \\
\hline ORF-1 & GQ478427 & ABC-type oligopeptide transport system (1e-121) & No & 2 & Yes & 60.35 \\
\hline ORF-2 & GQ478428 & ABC-type oligopeptide transport system (1e-114) & Yes & 1 & Yes & 61.10 \\
\hline ORF-4 & GQ478430 & ABC-type oligopeptide transport system (3e-73) & No & 1 & No & 36.04 \\
\hline ORF-5 & GQ478431 & ABC-type amino acid transport system (3e-61) & Yes & 1 & Yes & 30.52 \\
\hline ORF-6 & GQ478432 & ABC-type amino acid transport system (2e-61) & Yes & 1 & Yes & 30.31 \\
\hline
\end{tabular}

pilosicoli strain WesB, as previously described (Hampson et al., 2000). A total of $10^{8}$ formalinized WesB cells were emulsified in an equal volume of Freund's incomplete adjuvant (Sigma) in a total volume of $100 \mu \mathrm{l}$ and administered subcutaneously into five $\mathrm{C} 3 \mathrm{H} / \mathrm{HeJ}$ male mice of 5 weeks of age three times at 2 week intervals. Three weeks after the last inoculation, the mice were euthanized by methoxyflurane inhalation followed by cervical dislocation, blood was collected by cardiac puncture, and the serum was separated and stored at $-20{ }^{\circ} \mathrm{C}$ until used.

In vitro immunogenicity analysis. The recombinant proteins were tested by Western immunoblot with the mouse polyclonal antiserum against $B$. pilosicoli, as well as swine serum obtained from the Centre for Intestinal Spirochaete Research, Murdoch University. The sera originated from healthy pigs as well as animals naturally or experimentally infected with $B$. pilosicoli.

SDS-PAGE gels were used to separate $10 \mu \mathrm{g}$ of each recombinant $\mathrm{His}_{6}$ protein and these were electro-transferred to nitrocellulose membranes, which were blocked with TBS-T (Tris buffered saline supplemented with $0.05 \% \mathrm{v} / \mathrm{v}$ Tween 20) containing $5 \%(\mathrm{w} / \mathrm{v})$ skimmed milk powder, and assembled into a multi-probe apparatus. The mouse and pig sera were diluted 50-100-fold, and were added to the membranes, which were incubated for $1 \mathrm{~h}$ on a shaker at room temperature, and then washed three times with TBS-T. The membranes were reacted with a 1:5000 dilution of anti-pig or anti-mouse IgG-alkaline phosphate conjugate for $1 \mathrm{~h}$ at room temperature. The membranes were then developed with alkaline phosphatase developing buffer (BioRad), after three washes with Tris buffered saline.

In vivo immunogenicity analysis. Thirty-five $\mathrm{C} 3 \mathrm{H} / \mathrm{HeJ}$ male mice of 5 weeks of age were housed in seven groups of five in the Animal House at Murdoch University. Six groups of mice were injected subcutaneously twice, at a 2 week interval, with $100 \mu \mathrm{g}$ of the appropriate $\mathrm{His}_{6}$-protein, resuspended in $50 \mu \mathrm{lPB}$, and emulsified in an equal volume of Freund's incomplete adjuvant in a total volume of $100 \mu \mathrm{l}$. The last group of mice was left unvaccinated. Two weeks after the last inoculation, all the mice were euthanized and the blood was collected as described previously. The immunogenicity of each recombinant protein was confirmed using Western blot against whole-cell protein preparations of B. pilosicoli strain WesB and each recombinant $\mathrm{His}_{6}$-protein.

Vaccine efficacy study. Two selected recombinant proteins (P-1 and $\mathrm{P}-3$ ) were tested as candidate vaccine antigens against IS in $\mathrm{C} 3 \mathrm{H} /$ HeJ mice. Seventy-two female mice of 5 weeks of age were housed in six groups of twelve per cage. The mice were fed on a commercial pelleted basal mouse diet from their arrival until 10 days before the day of first infection with $B$. pilosicoli, when the diet was changed to a balanced diet containing $63 \%$ glucose that has been reported to support infection with B. pilosicoli in mice (Sacco et al., 1997). The mice were killed 16 days after the last day of experimental infection.

For each recombinant protein, 12 mice were used as a vaccinated/ non-infected group and 12 as a vaccinated/infected group. The mice were injected subcutaneously twice at a 2 week interval with $100 \mu \mathrm{g}$ of the appropriate $\mathrm{His}_{6}-\mathrm{P}$ recombinant protein emulsified in Freund's incomplete adjuvant in a total volume of $100 \mu$ l. Two control groups each of 12 mice were included, comprising non-vaccinated/infected (infection control) and non-vaccinated/non-infected (negative control) mice. Two weeks after the second vaccination, the mice in the vaccinated/non-infected groups were killed to obtain blood and intestinal samples to analyse systemic and local antibody responses to the vaccines. The mice in the vaccinated/infected groups, and the infection control group were deprived of water for $1 \mathrm{~h}$, then they were infected via gastric intubation with $500 \mu$ of fresh motile B. pilosicoli strain WesB culture at mid-exponential phase growth at a density of approximately $10^{8}$ cells $\mathrm{ml}^{-1}$. The inoculation procedure was repeated daily on the following 3 days. The negative control group was not infected and the mice were killed at the end of the experiment and blood and intestine samples collected.

Faecal sampling, culture and DNA detection. Faecal pellets (3-4) from each mouse were collected before vaccination, before infection and twice a week thereafter, starting 3 days after the last oral inoculation. Bacteriological swabs were inserted into the faeces, streaked onto selective TSA-CSV plates [TSA containing $20 \mu \mathrm{g}$ colistin $\mathrm{ml}^{-1}, 400 \mu \mathrm{g}$ spectinomycin $\mathrm{ml}^{-1}$ and $20 \mu \mathrm{g}$ vancomycin $\mathrm{ml}^{-1}$ (the antimicrobials were supplied by Sigma), and $5 \%$ defibrinated ovine blood] (Jenkinson \& Wingar, 1981), and incubated for $7-10$ days at $37{ }^{\circ} \mathrm{C}$ in an anaerobic environment before being examined. The presence of spirochaetes was identified by a zone of weak $\beta$-haemolysis surrounding a low flat haze of bacterial growth. The bacterial growth was examined by phase-contrast microscopy and then resuspended in $50 \mu \mathrm{l}$ lysis buffer [10mM Tris-HCl, $1 \mathrm{mM}$ EDTA $(\mathrm{pH}$ 8.0)]. The suspension was mixed by vortex and then heated in a boiling water bath for $5 \mathrm{~min}$. The extracts were subjected to a $B$. pilosicoli-specific PCR (La et al., 2003). The products were separated by electrophoresis in a $1.2 \%$ agarose gel, stained by immersion for $30 \mathrm{~min}$ in $5 \mu \mathrm{g}$ ethidium bromide $\mathrm{ml}^{-1}$ solution, and viewed with $\mathrm{UV}$ light.

Similar faecal samples collected pre-vaccination, post-vaccination and at post-mortem were prepared for measuring antibody content. A $500 \mu \mathrm{l}$ volume of cold PBS containing $5 \%$ skimmed milk and $0.5 \%$ proteinase inhibitor was added to each sample, which was incubated at $4{ }^{\circ} \mathrm{C}$ overnight until dissolved. After mixing by vortex the supernatant was collected by centrifugation at $16000 \mathrm{~g}$ for $10 \mathrm{~min}$ and stored at $-20{ }^{\circ} \mathrm{C}$ until used. Blood collected by post-mortem 
heart puncture was allowed to stand overnight at $4{ }^{\circ} \mathrm{C}$, the clot was removed and the serum was centrifuged at $2000 \mathrm{~g}$ for $10 \mathrm{~min}$ at $4{ }^{\circ} \mathrm{C}$ to pellet the debris. The sera were removed, mixed with an equal volume of $100 \%$ glycerol and stored at $-20{ }^{\circ} \mathrm{C}$.

Post-mortem tissue and faecal samples. The luminal surfaces of the caecal and colon walls were rubbed with sterile bacteriological swabs, and the swabs cultured for B. pilosicoli as described for the faecal swabs. Contents equal to 3-4 faecal pellets were collected from the caecum and colon into $500 \mu \mathrm{l}$ cold PBS containing $5 \%$ skimmed milk and $0.5 \%$ proteinase inhibitor for antibody quantification. Sections of the caecal and colon walls were excised and rinsed in cold PBS to remove digesta, and then were placed in $10 \%(\mathrm{v} / \mathrm{v})$ buffered formalin for histological examination. The fixed tissue was processed through to paraffin blocks, cut at $4 \mu \mathrm{m}$, and stained with haematoxylin and eosin.

Assays for antibody responses. After being optimized, ELISAs and Western immunoblots were used to evaluate the systemic and mucosal IgG and IgA responses against the recombinant proteins. The ELISA used $100 \mathrm{ng}$ either of each recombinant protein or of a wholecell protein preparation of $B$. pilosicoli per well in $0.1 \mathrm{M}$ carbonate buffer ( $\mathrm{pH}$ 9.6) plus blocking solution (TBS-T containing $5 \%(\mathrm{w} / \mathrm{v})$ skimmed milk powder) and mouse serum $(1: 200)$ or faecal extract $(1: 2)$. Positive ELISA samples also were analysed by Western blot using either $3000 \mathrm{ng}$ recombinant protein or $5000 \mathrm{ng}$ whole cell $B$. pilosicoli protein preparation as antigen. The procedure was as previously described except that goat anti-mouse IgG-HRP (horseradish peroxidase) or IgA-HRP conjugate at $1: 4000$ dilution was used to detect mouse primary antibodies, and HRP substrate solution (HRP $10 \mathrm{mg}, 16.6 \mathrm{ml}$ PBS $\mathrm{pH} 7.4,3.325 \mathrm{ml}$ methanol and $10 \mu \mathrm{l}$ hydrogen peroxide) was used to develop the colour.

Data analysis and statistics. Comparisons were made between the groups of mice. The ELISA values for group systemic and local IgG were calculated as means \pm SDs. The statistical differences of the ELISA values between groups of mice in each experiment were analysed using one-way analysis of variance (ANOVA) (in Microsoft Office Excel). Faecal excretion of B. pilosicoli for each animal in each group was recorded as positive or negative to create a simple ratio of infected samples per total samples collected for each group. The ratios for each group were compared using $\chi^{2}$ analysis, with pairs of observations subsequently analysed using Fischer's exact test.

\section{RESULTS}

\section{Characteristics and distribution of selected ORFs}

A summary of the bioinformatics analysis on the six selected ORFs is presented in Table 1 . The ORFs were predicted to encode membrane-associated periplasmic proteins involved in ABC-type oligopeptide or amino acid transport. PCR analysis identified all six ORFs in 93-100\% of the 27 B. pilosicoli strains tested. ORF-1 and ORF-2 were not amplified from two Australian porcine strains of $B$. pilosicoli, and ORF-3 was not amplified from another Australian porcine strain. The other three ORFs were amplified from all the strains (Table 1).

\section{Recombinant protein expression, purification and immunogenicity}

All six proteins were successfully expressed in E. coli BL21, and purified by affinity chromatography. The molecular masses of the mature proteins as seen on the SDS-PAGE gels were similar to their predicted masses (Table 1). Five were strongly immunoreactive in Western immunoblots with a set of sera from convalescent pigs, while P-4 was weakly reactive. A similar pattern was seen with mouse sera raised against a bacterin preparation of B. pilosicoli strain WesB. Weak Western blot reactivities also were observed between the negative control sera and all the proteins except for P-4. Sera obtained by immunizing mice with the proteins were immunoreactive with their corresponding recombinant proteins, and with their specific native proteins in the whole cell preparation of B. pilosicoli strain WesB. Results for recombinant proteins $\mathrm{P}-1$ and P-3 are shown in Fig. 1.

\section{Antibody responses in vaccinated and infected mice}

The systemic and large intestinal IgG responses of the mice immunized with $\mathrm{P}-1$ and $\mathrm{P}-3$ in the vaccine experiment are summarized in Table 2. Vaccinated mice had significantly more serum IgG against the corresponding proteins than did non-vaccinated mice. In contrast, infection alone did not significantly increase antibody levels to these proteins. Vaccination with P-1 but not P-3 resulted in a further significant increase in serum antibody levels in vaccinated infected mice compared to vaccinated non-infected mice. Vaccination also resulted in a significant increase in local IgG levels to the corresponding proteins in the mixed samples from the caecae and colons, although this increase was considerably greater with P-1 than with P-3. Infection also resulted in significant increases in IgG levels in the case of P-1. Infection of vaccinated mice only further significantly increased IgG levels in the case of P-3. No IgA to the recombinant proteins was detected (Table 2).

\section{Faecal shedding of $B$. pilosicoli}

The colonization rates are summarized in Table 3. No mice were colonized pre-infection. Colonization was first observed at day 6, and was greatest at day 16, when 9 of the 12 control mice were colonized. The ratio of positive samples/total samples obtained was significantly greater $(P<0.001)$ for the infection control mice compared to both groups of vaccinated mice. Significantly fewer mice vaccinated with $\mathrm{P}-1$ were colonized compared to the control mice $(P=0.012)$, but differences in numbers were not significant for the mice vaccinated with P-3 (Table 3).

\section{Clinical signs and pathological changes}

The caecae and colons of the colonized mice did not show obvious gross changes compared to those of non-colonized mice. Histological examination revealed some mild abnormalities, such as an increase in the number of goblet cells and focal disruption of the epithelium in both caecal and colonic samples of the colonized mice, but no end-on attachment of spirochaetes to enterocytes was observed. 
(a)

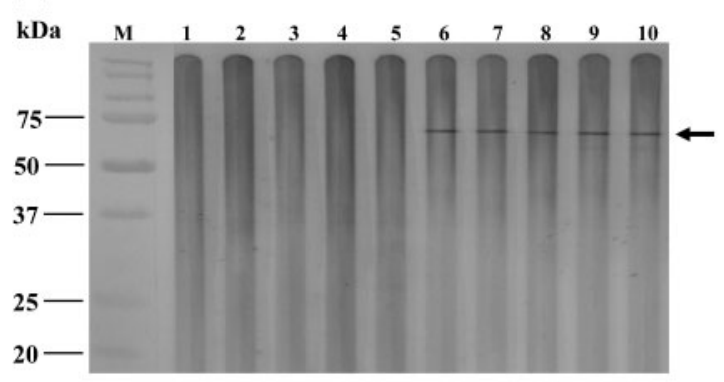

(c)

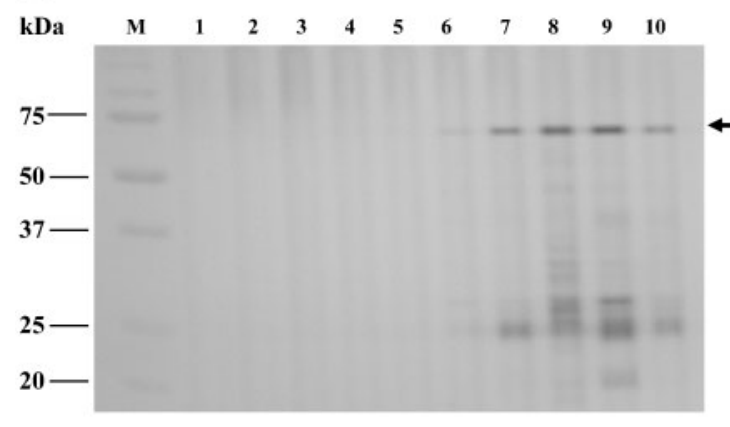

(b)

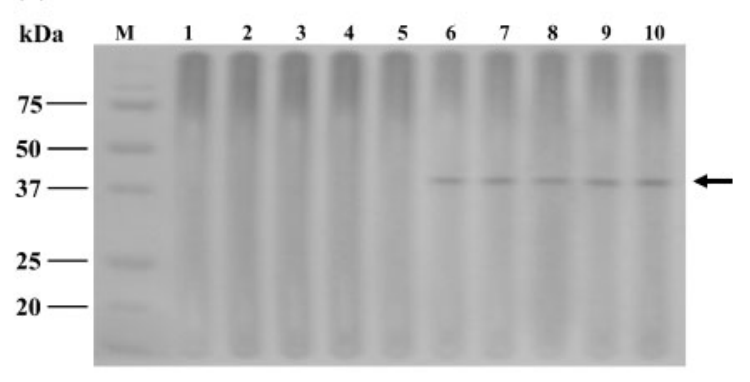

(d)

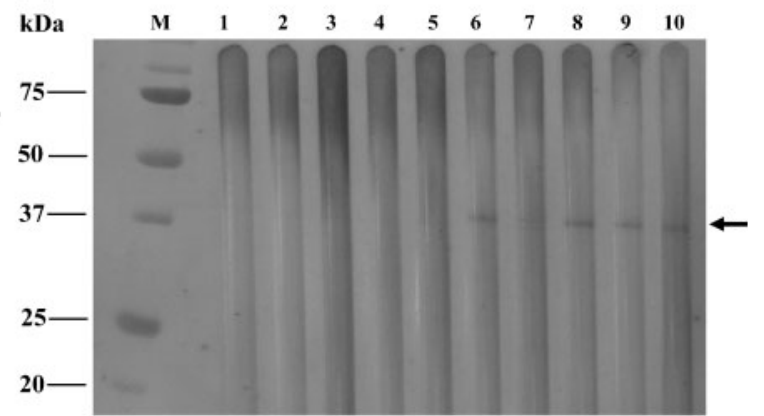

Fig. 1. Western immunoblots showing the reactivities of the two recombinant proteins used in the mouse vaccination experiments. Reactivity of recombinant $\mathrm{P}-1$ (a) and $\mathrm{P}-3$ (b) with serum from mice immunized with these proteins. (c, d) Reactivity of the same mouse sera shown in (a) and (b), respectively, with a whole cell preparation of $B$. pilosicoli strain WesB. Lanes 1-5, serum samples from non-vaccinated mice; lanes 6-10, serum samples from mice vaccinated with the respective recombinant proteins; lane $\mathrm{M}$, protein mass marker. The arrows indicate the positions of the reactive proteins, where molecular masses were similar to the predicted molecular masses (Table 1).

\section{DISCUSSION}

The mouse model of IS adapted in the current study was based on that used by Sacco et al. (1997), including feeding a disaccharide-rich diet and using $\mathrm{C} 3 \mathrm{H} / \mathrm{HeJ}$ mice. The model worked reasonably well, with $75 \%$ of the nonvaccinated control animals becoming colonized; however, end-on attachment of spirochaetes was not observed, and colonization did not induce clinical signs or consistent pathological changes. In a previous study, the same $B$. pilosicoli strain (WesB) similarly failed to attach to colonic enterocytes or cause obvious pathology in a mouse model of IS (Jamshidian et al., 2004). Despite this limitation, vaccine efficacy could be judged in relation to colonization rates in this model.

The aim of the study was to determine whether immunization with Opp-like oligopeptide-binding proteins from B. pilosicoli could protect from IS, based on the report that recombinant Opp has shown efficacy against $Y$. pestis infection in mice (Tanabe et al., 2006). To achieve this, a small number of genes predicted to encode membrane-associated oligopeptide-binding proteins in $B$. pilosicoli were selected from an incomplete genome

Table 2. Means and SDs of group systemic and local large intestinal lgG levels $\left(\mathrm{OD}_{450}\right.$ values) against the recombinant proteins in vaccinated and non-vaccinated mice that were either not infected or infected with $B$. pilosicoli

\begin{tabular}{|c|c|c|c|c|c|c|}
\hline \multirow{2}{*}{$\begin{array}{l}\text { ELISA antigen/ } \\
\text { vaccine group }\end{array}$} & \multirow{2}{*}{ Antibody } & \multicolumn{2}{|c|}{ Non-infected } & \multicolumn{2}{|c|}{ Infected } & \multirow{2}{*}{$\begin{array}{c}P \text { value } \\
(\text { ANOVA })^{\star}\end{array}$} \\
\hline & & Non-vaccinated & Vaccinated & Non-vaccinated & Vaccinated & \\
\hline P-1 & Local & $0.036 \pm 0.004^{\mathrm{a}}$ & $1.263 \pm 0.47^{\mathrm{c}}$ & $0.101 \pm 0.036^{\mathrm{b}}$ & $1.434 \pm 0.581^{\mathrm{c}}$ & $<0.001$ \\
\hline \multirow[t]{2}{*}{ P-3 } & Systemic & $0.134 \pm 0.059^{\mathrm{a}}$ & $2.195 \pm 0.444^{\mathrm{b}}$ & $0.078 \pm 0.012^{\mathrm{a}}$ & $2.608 \pm 0.417^{\mathrm{b}}$ & $<0.001$ \\
\hline & Local & $0.040 \pm 0.004^{\mathrm{a}}$ & $0.192 \pm 0.089^{\mathrm{b}}$ & $0.058 \pm 0.007^{\mathrm{a}}$ & $0.327 \pm 0.117^{\mathrm{c}}$ & $<0.001$ \\
\hline
\end{tabular}

${ }^{*}$ Within each row, values with a different superscript letter differ at the $5 \%$ level of significance. 
Table 3. Number of colonized mice and cumulative group colonization results for the groups of 12 vaccinated and non-vaccinated mice orally challenged with $B$. pilosicoli

\begin{tabular}{|c|c|c|c|c|c|c|c|}
\hline \multirow[t]{2}{*}{ Group } & \multicolumn{5}{|c|}{ Time post-infection (days) } & \multirow{2}{*}{$\begin{array}{l}\text { Positive samples/ } \\
\text { total samples }\end{array}$} & \multirow{2}{*}{$\begin{array}{c}\text { No. of colonized } \\
\text { mice } \dagger\end{array}$} \\
\hline & 3 & 6 & 9 & 12 & 16 & & \\
\hline $\mathrm{P}-1$ vaccinated & 0 & 1 & 2 & 2 & 2 & $7 / 60$ & 2 \\
\hline P-3 vaccinated & 0 & 2 & 3 & 3 & 4 & $12 / 60$ & 5 \\
\hline Infection control & 0 & 4 & 7 & 9 & 9 & $29 / 60$ & 9 \\
\hline
\end{tabular}

${ }^{\star}$ The ratio was significantly greater $(P<0.001)$ for the infection control mice compared to both groups of vaccinated mice.

$\dagger$ Significantly fewer mice vaccinated with P-1 were colonized compared to the control mice $(P=0.012)$. Other differences were not significant.

sequence. Clearly, in future studies, it also would be possible to use the same 'reverse vaccinology' process, starting with the genome sequence, to select and test other classes of potential vaccine candidates, such as outermembrane lipoproteins and secreted proteins (Movahedi \& Hampson, 2008). The genes that were selected in the current study were widely distributed amongst different $B$. pilosicoli strains, indicating that if the products were effective as vaccine components against one strain they probably would be effective against a wide range of strains. The corresponding recombinant proteins were all immunogenic in mice, and they were recognized by serum from naturally or experimentally infected pigs. This finding supported the likelihood that these molecules could induce an immune response with potential to protect from infection. Reactivity to P-4 was weaker than to the other proteins, and so it was excluded on that basis. Interestingly, P-4 was the only molecule that was not predicted to be a lipoprotein. P-5 and P-6 were predicted to be involved in amino acid transport rather than oligopeptide transport, so these were not selected for testing in mice. Two of the remaining three recombinant proteins were predicted to have signal peptides, suggesting that they were secretory, and one of each sort were selected for testing in the mouse model of IS.

As anticipated, the experimental vaccines induced significant increases in systemic IgG levels against the corresponding proteins. The subcutaneous route of vaccine administration induced a mucosal IgG antibody response in the large intestine, although this was only relatively high in the case of P-1. Infection alone also induced a similar local response against $\mathrm{P}-1$. Infection of vaccinated mice further significantly increased systemic IgG only in the case of $\mathrm{P}-1$, whereas there was an increased antibody response to $\mathrm{P}-3$ but not to $\mathrm{P}-1$ following infection of the vaccinated mice. The lack of a local IgA response in the infected mice was unexpected, but in part this may reflect the relatively short period that the mice were kept in the experiments.

Both vaccinated groups had significantly fewer days of colonization than did the infection control group, hence providing evidence that the vaccines were having some effect in reducing colonization. Furthermore, vaccination with $\mathrm{P}-1$, which induced the highest levels of systemic and local IgG, also significantly reduced the number of colonized mice. Further studies are now required to test these recombinant proteins as vaccine candidates in other natural hosts, such as chickens and pigs. In addition, a more detailed investigation of the structure and function of these predicted oligopeptide-binding proteins is required.

\section{ACKNOWLEDGEMENTS}

The authors thank Novartis Animal Vaccines for financial support for this study. We gratefully acknowledge the Razi Vaccine and Serum Research Institute, Iran, and the Ministry of Health and Medical Education of the Islamic Republic of Iran for their postgraduate scholarship to Dr Movahedi. We thank Professor Matthew Bellgard for bioinformatics support and Dr Tom La for advice, and for helpful comments on the manuscript.

\section{REFERENCES}

Altschul, S. F., Gish, W., Miller, W., Myers, E. W. \& Lipman, D. J. (1990). Basic local alignment search tool. J Mol Biol 215, 403410.

Bait-Merabet, L., Thille, A., Legrand, P., Brun-Buisson, C. \& Cattoir, V. (2008). Brachyspira pilosicoli bloodstream infections: case report and review of the literature. Ann Clin Microbiol Antimicrob 7, 19.

Bateman, A., Ewan Birney, E., Cerruti, L., Durbin, R., Etwiller, L., Eddy, S. R., Jones, S. G., Howe, K. L., Marshall, M. \& Sonnhammer, E. L. L. (2002). The Pfam protein families database. Nucleic Acids Res 30, 276-280.

Bendtsen, J. D., Nielsen, H., Von Heijne, G. \& Brunak, S. (2004). Improved prediction of signal peptides: SignalP 3.0. J Mol Biol 340, 783-795.

Brooke, C. J., Riley, T. V. \& Hampson, D. J. (2006). Comparison of prevalence and risk factors for faecal carriage of the intestinal spirochaetes Brachyspira aalborgi and Brachyspira pilosicoli in four Australian populations. Epidemiol Infect 134, 627-634.

Douglas, J. G. \& Crucioli, V. (1981). Spirochaetosis: a remediable cause of diarrhoea and rectal bleeding? $\mathrm{Br}$ Med J (Clin Res Ed) 283, 1362.

Esteve, M., Salas, A., Fernández-Banares, F., Lloreta, J., Mariné, M., Gonzalez, C. I., Forné, M., Casalots, J., Santaolalla, R., Espinós, J. C. \& other authors (2006). Intestinal spirochetosis and chronic watery diarrhea: clinical and histological response to treatment and longterm follow-up. J Gastroenterol Hepatol 21, 1326-1333. 
Ewing, B., Hillier, L., Wendl, M. C. \& Green, P. (1998). Base-calling of automated sequencer traces using Phred. I. Accuracy assessment. Genome Res 8, 175-185.

Fournié-Amazouz, E., Baranton, G., Carlierf, J. P., Chambreuil, G., Cohadon, F., Collin, P., Gougeon Jolivet, A., Hermès, I., Lemarie, C. \& Saint Girons, I. (1995). Isolations of intestinal spirochaetes from the blood of human patients. J Hosp Infect 30, 160-162.

Gordon, D., Abajian, C. \& Green, P. (1998). Consed: a graphical tool for sequence finishing. Genome Res 8, 195-202.

Hampson, D. J. \& Duhamel, G. E. (2006). Porcine colonic spirochetosis/intestinal spirochetosis. In Diseases of Swine, 9th edn, pp. 755-767. Edited by B. E. Straw, J. J. Zimmerman, S. D’Allaire \& D. J. Taylor. Oxford: Blackwell Publishing.

Hampson, D. J. \& Swayne, D. E. (2008). Avian intestinal Spirochetosis. In Diseases of Poultry, 12th edn, pp. 922-940. Edited by Y. M. Saif. Oxford: Blackwell Publishing.

Hampson, D. J., Robertson, I. D., La, T., Oxberry, S. L. \& Pethick, D. W. (2000). Influences of diet and vaccination on colonisation of pigs by the intestinal spirochaete Brachyspira (Serpulina) pilosicoli. Vet Microbiol 73, 75-84.

Hampson, D. J., Oxberry, S. L. \& La, T. (2006). Potential for zoonotic transmission of Brachyspira pilosicoli. Emerg Infect Dis 12, 869-870.

Hiron, A., Borezée-Durant, E., Piard, J. C. \& Juillard, V. (2007). Only one of four oligopeptide transport systems mediates nitrogen nutrition in Staphylococcus aureus. J Bacteriol 189, 5119-5129.

Jamshidian, M., La, T., Phillips, N. D. \& Hampson, D. J. (2004). Brachyspira pilosicoli colonization in experimentally infected mice can be facilitated by dietary manipulation. J Med Microbiol 53, 313-318.

Jenkinson, S. R. \& Wingar, C. R. (1981). Selective medium for the isolation of Treponema hyodysenteriae. Vet Rec 109, 384-385.

Kanavaki, S., Mantadakis, E., Thomakos, N., Pefanis, A., MatsiotaBernard, P., Karabela, S. \& Samonis, G. (2002). Brachyspira (Serpulina) pilosicoli spirochetemia in an immunocompromised patient. Infection 30, 175-177.

Käsbohrer, A., Gelderblom, H. R., Arasteh, K., Heise, W., Grosse, G., L'age, M., Schönberg, A., Koch, M. A. \& Pauli, G. (1990). Intestinal spirochetosis in HIV infection: prevalence, isolation and morphology of spirochetes. Dtsch Med Wochenschr 115, 1499-1506 (in German).

Kunkle, R. A., Harris, D. L. \& Kinyon, J. M. (1986). Autoclaved liquid medium for propagation of Treponema hyodysenteriae. J Clin Microbiol 24, 669-671.

La, T., Phillips, N. D. \& Hampson, D. J. (2003). Development of a duplex PCR assay for detection of Brachyspira hyodysenteriae and Brachyspira pilosicoli in pig feces. J Clin Microbiol 41, 3372-3375.

La, T., Phillips, N. D., Reichel, M. P. \& Hampson, D. J. (2004). Protection of pigs from swine dysentery by vaccination with recombinant $\mathrm{BmpB}$, a $29.7 \mathrm{kDa}$ outer-membrane lipoprotein of Brachyspira hyodysenteriae. Vet Microbiol 102, 97-109.

Lee, J. I. \& Hampson, D. J. (1992). Intestinal spirochaetes colonizing Aborigines from communities in the remote north of Western Australia. Epidemiol Infect 109, 133-141.

Lukashin, A. V. \& Borodovsky, M. (1998). GeneMark.hmm: new solutions for gene finding. Nucleic Acids Res 26, 1107-1115.

Marchler-Bauer, A., Anderson, J. B., DeWeese-Scott, C., Fedorova, N. D., Geer, L. Y., He, S., Hurwitz, D. I., Jackson, J. D., Jacobs, A. R. \& other authors (2003). CDD: a curated Entrez database of conserved domain alignments. Nucleic Acids Res 31, 383-387.

Margawani, K. R., Robertson, I. D., Brooke, C. J. \& Hampson, D. J. (2004). Prevalence, risk factors and molecular epidemiology of
Brachyspira pilosicoli in humans on the island of Bali, Indonesia. $J$ Med Microbiol 53, 325-332.

Mortimer-Jones, S. M., Phillips, N. D., La, T., Naresh, R. \& Hampson, D. J. (2008). Penicillin resistance in the intestinal spirochaete Brachyspira pilosicoli associated with OXA-136 and OXA-137, two new variants of the class D $\beta$-lactamase OXA-63. J Med Microbiol 57, 1122-1128.

Motro, Y., Dunn, D. S., La, T., Phillips, N. D., Hampson, D. J. \& Bellgard, M. I. (2008). Intestinal spirochaetes of the genus Brachyspira share a partially conserved 26 kilobase genomic region with Enterococcus faecalis and Escherichia coli. Microbiol Insights 1, 3-11.

Movahedi, A. R. \& Hampson, D. J. (2008). New ways to identify novel bacterial antigens for vaccine development. Vet Microbiol 131, $1-13$.

Nakai, K. (2000). Protein sorting signals and prediction of subcellular localization. Adv Protein Chem 54, 277-344.

Nowalk, A. J., Gilmore, R. D., Jr \& Carroll, J. A. (2006). Serologic proteome analysis of Borrelia burgdorferi membrane-associated proteins. Infect Immun 74, 3864-3873.

Peghini, P. L., Guccion, J. G. \& Sharma, A. (2000). Improvement of chronic diarrhea after treatment for intestinal spirochetosis. Dig Dis Sci 45, 1006-1010.

Sacco, R. E., Trampel, D. W. \& Wannemuehler, M. J. (1997). Experimental infection of $\mathrm{C} 3 \mathrm{H}$ mice with avian, porcine, or human isolates of Serpulina pilosicoli. Infect Immun 65, 5349-5353.

Salzberg, S. L., Pertea, M., Delcher, A. L., Gardner, M. J. \& Tettelin, H. (1999). Interpolated Markov models for eukaryotic gene finding. Genomics 59, 24-31.

Song, Y., La, T., Phillips, N. D., Bellgard, M. I. \& Hampson, D. J. (2009). A reverse vaccinology approach to swine dysentery vaccine development. Vet Microbiol 137, 111-119.

Tanabe, M., Atkins, H. S., Harland, D. N., Elvin, S. J., Stagg, A. J., Mirza, O., Titball, R. W., Byrne, B. \& Brown, K. A. (2006). The ABC transporter protein OppA provides protection against experimental Yersinia pestis infection. Infect Immun 74, 3687-3691.

Trivett-Moore, N. L., Gilbert, G. L., Law, C. L. H., Trott, D. J. \& Hampson, D. J. (1998). Isolation of Serpulina pilosicoli from rectal biopsy specimens showing evidence of intestinal spirochaetosis. J Clin Microbiol 36, 261-265.

Trott, D. J., Combs, B. G., Mikosza, A. S., Oxberry, S. L., Robertson, I. D., Passey, M., Taime, J., Sehuko, R., Alpers, M. P. \& Hampson, D. J. (1997a). The prevalence of Serpulina pilosicoli in humans and domestic animals in the Eastern Highlands of Papua New Guinea. Epidemiol Infect 119, 369-379.

Trott, D. J., Jensen, N. S., Saint Girons, I., Oxberry, S. L., Stanton, T. B., Lindquist, D. \& Hampson, D. J. (1997b). Identification and characterisation of Serpulina pilosicoli isolates from the blood of critically-ill patients. J Clin Microbiol 35, 482-485.

Veith, P. D., Dashper, S. G., O'Brien-Simpson, N. M., Paolini, R. A., Orth, R., Walsh, K. A. \& Reynolds, E. C. (2009). Major proteins and antigens of Treponema denticola. Biochim Biophys Acta 1794, 14211432.

Wu, T. K., Wang, Y. K., Chen, Y. C., Feng, J. M., Liu, Y. H. \& Wang, T. Y. (2007). Identification of a Vibrio furnissii oligopeptide permease and characterization of its in vitro hemolytic activity. J Bacteriol 189, 8215-8223.

Zeeshan, M., Irfan, S. \& Ahmed, I. (2009). Brachyspira species blood stream infection. J Pak Med Assoc 59, 723-724. 